\title{
Risk factors of pressure ulcers among traumatized patients
}

\author{
Ragaa Dahi Mohammed, Assist \& Alaa Mohamed Ahmed Atyea, Mona Aly Mohammed \& Dr. Mervat \\ Anwar Abd El-Aziz
}

Demonstration of Critical care nursing department, faculty of nursing, South Valley University. Assist Professor of Anesthesia and Intensive Care Department, Faculty of Medicine, Assuit University

Lecturer in Critical Care Nursing Department, Faculty of Nursing, Assuit University.

\begin{abstract}
Critically ill patients are at a higher risk for pressure ulcers than patients in general care unites. Several factors increase the risk: severity of illness; increased length of stay; poor tissue perfusion due to hemodynamic instability, use of vasoactive medications, anemia; sensory impairment, skin maceration due to moisture; immobility; and poor nutritional status. Aim: the aim of this study is to assess the risk factors of pressure ulcers among traumatized patients. Design: descriptive research design was used to conduct this research. Setting: this study was carried out at Trauma ICU at Assiut University Hospitals. Subjects: sample of this study included 60 adult patients. Tools: two tools were used for data collection in this study. Results: The main results revealed that most of study sample aged between 41- 60 years old, and there was a significant difference between the age groups. Results also indicated a significant difference between the studied samples in relation to the different risk factors. There was a significance difference in the studied patients in relation to the temperature. As regard the Braden scale assessment, it was found a significance difference between the studied patients in relation to the sub items of the scale. Conclusion: proper assessment of the patients for pressure ulcer risk factors is very important for prevention.
\end{abstract}

\section{Key Words: Risk Factor, Pressure Ulcer, Traumatized Patients.}

\section{Introduction}

A pressure ulcer is defined as Localized injury to the skin and/or underlying tissue usually over a bony prominence, as a result of pressure, or pressure in combination with shear. Tissue damage can occur with high pressures over short periods of time or low pressures over long periods of time (Crane, 2014). Critically ill patients are at particular risk for development of pressure ulcers. Risk factors include unrelieved pressure, friction, shear, decreased mobility, edema, malnutrition, moisture, high temperature, and some received treatments (eg, vasopressors) (Cullum, 2001\& Thompson, 2005). Critically ill patients usually have multiple risk factors for the development of pressure ulcers. Pressure ulcers are the third most expensive disorder after cancer and cardiovascular diseases. (Eman, 2009). In addition, about 57-60 \% of all pressure ulcers occur within hospitals (Thomas, 2001). In intensive care units about $13 \%$ of patients treated from developed pressure sores. Pressure ulcer can develop in a short time, it can appear within a few hours postoperatively, but most usually occur 1 to 3 days after surgery (Karadag, 2006).

Two factors may influence the development of pressure ulcers in hospitalized critically ill patients: intrinsic factors particular to each patient and extrinsic or environmental factors. Intrinsic risk factors of importance include age, comorbid conditions, nutritional status, body size, mobility status, activity level, and body temperature. Extrinsic factors that intensify the effects of other risk factors include heat, shearing, friction, and moisture (Armstrong, 2001).

Malnutrition has been also associated with the development of pressure ulcers, lower dietary protein intake and inability to feed oneself have been found to be independently predictive of PU development (Reilly et al., 2007). Urinary and fecal incontinence are considered to be predictive of PU development, at least since the validation of the early predictive instruments. (Reilly et al., 2007).

The Braden Scale is the most widely used risk assessment tool in the most care settings, including the ICU, and current clinical practice guidelines (Lyder \& Ayello, 2008 \& NPUAP\&EPUAP, 2009) recommended its use. With the Braden Scale, derived from the conceptual framework of Braden and Bergstrom, 6 subscales are used to measure risk for pressure ulcers: sensory perception, activity, mobility, nutrition, moisture, and friction/ shear. Potential scores range from 6 to 23; lower scores indicate greater risk. Scores of 15 to 18 indicate mild risk; scores of 13 to 14 , moderate risk; scores of 10 to 12, high risk; and scores of 9 or less, very high risk (Braden, 2011). Stratification of risk for pressure ulcers can be useful clinically for determining and implementing the appropriate level of prevention (Ayello \& Braden, 2002). 
Relief of pressure by regular repositioning and the use of alternating air flow mattresses is a major consideration for ICU patients while in bed, but less emphasis has been placed on measures to promote comfort and reduce pressure when patients are sitting out of bed (Williams, 2012).

Significance of the study:

Statistics of Egyptian trauma Intensive Care Unit at Assiut University Hospital in the years of (2010 \& 2011) revealed that the number of patients admitted to the trauma intensive care unit were $775,75 \%$ of them were connected to mechanical ventilation. (Hospital records of Assiut University 2010-2011). Clinical observation of the researcher revealed that most of those patients were high risk for pressure ulcers which might endanger their life, increase hospital stay, morbidity and mortality to critically ill patients. . Every patient in ICU is potentially at risk for developing pressure ulcers due to immobility, decreased sensory perception, low albumin levels, altered nutrition status and medications.

\section{Aim of the study}

The aim of the current study is to assess the pressure ulcers risk factors among traumatized patients.

Patients and Methods

Research design: Descriptive research design was used to conduct this study.

\section{Sample}

A convenience sample of 60 critically ill patients who were admitted to the trauma ICU

\section{Setting of the study}

The study was conducted in the intensive trauma unit at Assiut University Hospital

\section{Study tools:-}

Second tools were utilized to collect data in this study.

First Tool: "Pressure ulcer risk factors assessment"

The Braden scale to assess Skin state. (Cox, 2011).

The Braden scale was used to assess the risk of developing pressure ulcer. This scale divided into six types: sensory perception, activity, mobility, nutrition, moisture, and friction/ shear. Potential scores range from 6 to 23; lower scores indicate greater risk. Scores of 15 to 18 indicate no risk or mild risk; scores of 13 to 14, moderate risk; scores of 10 to 12 , high risk; and scores of 9 or less, very high risk. Stratification of risk for pressure ulcers can be useful clinically for determining and implementing the appropriate level of prevention. (Cox, 2011). The researcher made the scale daily for 7 days.

Scoring System of the BRADEN SCALE

Severe Risk: Total score $\leq 9$
High Risk: Total score 10-12

Moderate Risk: Total score 13

Mild Risk: Total score 15-18

Second tool

Assessment of patient profile.

This tool was developed by the researcher based on reviewing of the relevant literature, it includes six main parts as flowing.

Part I: Socio- demographic and clinical data form Which include age \& sex, and medical related data of the patients, as blood gases measurements which include arterial oxygen tension (pao2), arterial carbon dioxide tension (paco2), oxygen saturation (Sao2), $\mathrm{PH}, \mathrm{Hco} 3$ and BE.

Part II- Anthropometric measurements

Which includes patient's weight, height, body mass index and mid arm circumference. Body mass index (BMI) was classified as follows: less than 18.5, underweight; (18.5 to 24.9), normal; (25.0 to 29.9), overweight; and higher than (30.0) obese (Dickinson, 2013). Body Mass Index (BMI) calculated as the weight in kilograms divided by the height in meters squared (using the admission weight and height) (Tschannen, 2012).

Part III: Hemodynamic parameters: that includes assessment of temperature, pulse, blood pressure, respiration, and pulse oximetry measurements.

Part IV: Ventilator parameters at time of the study if the patient is connected with it: (Tidal volume (vt), Respiratory rate (R.r) and Fraction of inspired oxygen (fio)

Part VI: Glasgow Coma Scale for Neurological assessment: (Green, S.M 2011).

Taken by the researcher daily for 7 days.

The scale comprises three tests: Best eye response (E) There are 4 grades starting with the most severe, Best verbal response (V) There are 5 grades starting with the most severe, and Best motor response (M) There are 6 grades starting with the most severe responses.

\section{Scoring system:-}

- Severe, with GCS $\leq 8$

- Moderate, GCS 9 - 12

- Mild GCS $\geq 13$.

Part VII: Fluid Balance Assessment that includes assessment of the fluid balance by calculating the total intake and output over 24 hour and then the total balance.

Methods

The study was conducted through main phases as following.

\section{Preparatory phase}

- Official permission from the faculty of nursing to conduct the study was delivered to the hospital authorities in Assuit university hospital and approval to conduct this study was obtained. 
- Informed consent was obtained from the head of the trauma intensive care unit and head.

- The tools were developed by the researcher based upon review of the related literatures.

- The validity and reliability of these tools were revised by a panel of critical care nursing and medical experts, and the necessary modification were done based on the expert's suggestions.

\section{A Pilot study}

- A pilot study was carried out before starting of data collection to test the feasibility and clarity of the study tools on $10 \%$ of the sample, those selected patients don't included in the main study sample. It had also provided an estimate of time needed to fill out the tools. The necessary modification was done prior to data collection

\section{Data collection}

Data were collected in a period of 6 months starting from the beginning of November 2012 to the end of April 2013. The data were collected from the first day of admission and for seven days subsequently.

- The patient hemodynamic state including (Temperature, pulse, respiration, blood pressure, pulse oximetry) were assessed manually every shift for one week.

- Arterial blood gases including (PH, Paco2, pao2 $\mathrm{HCo} 3$, and $\mathrm{BE}$ ) were assessed according to patient condition.

- The neurological state of the patient was assessed using the Glasgow Coma Scale (GCS) to assess patient level of consciousness.

- Calculated total Intake (oral, intravenous, entral feeding) and total output (urine, emesis, feces and drainages) every 24 hour.

- Assess the parameters of mechanical ventilation if patient connected with it as (mode, friction of inspired oxygen \&PEEP).

- Braden Scale used to assess skin states assessed high risk patients for pressure ulcer made this the scale every day for one week.

\section{Ethical considerations}

- the nature and purpose of the study was explained to every patient and to the relatives in case of unconscious patients and the Confidentiality and anonymity were assured to the patients.

- Patients were assured that they have the right to refuse to participate and/or withdraw from the study without any rational at any time.

- Patients were assured that the data of this research will not be reused without second permission.

\section{Statistical analysis}

All data were recorded in a special chart for every patient. The collected data were coded, analyzed and tabulated. Data entry and analysis were done using SPSS 17.0 statistical software package. Data were presented using descriptive statistics in the form of frequencies and percentages for qualitative variables, and means and standard deviations for quantitative variables. Quantitative continuous data were compared using analysis of variance test in case of comparisons between two independent groups. ChiSquare test was used for non-parametric data to determine the significance. Statistical significant differences were considered when P-value used as follows. $\mathrm{P}>0.05$ non-significant, $* \mathrm{P}<0.05$ significant, $* * \mathrm{P}<0.001$ moderate significant, $* * * \mathrm{P}<$ 0.0001 highly significant. 


\section{Results}

Table (1): Frequency distribution of the study sample in relation to the socio-demographic characteristics $(\mathbf{n}=60)$

\begin{tabular}{|c|c|c|c|c|}
\hline \multicolumn{3}{|c|}{$\begin{array}{c}\text { Socio-demographic characteristics } \\
\text { of Study sample }(\mathrm{N}=60)\end{array}$} & \multirow[t]{2}{*}{ Chi-Square } & \multirow[t]{2}{*}{ P. value } \\
\hline 1- Age "years." & $\mathbf{N}$ & $\%$ & & \\
\hline$<20$.years & 5 & 8.33 & \multirow{4}{*}{21.5} & \multirow{4}{*}{$0.001 * *$} \\
\hline 20-40ys. & 16 & 26.67 & & \\
\hline 41-60ys. & 29 & 48.33 & & \\
\hline$>60 y s$. & 10 & 16.67 & & \\
\hline \multicolumn{5}{|l|}{ Sex } \\
\hline Male & 51 & 85.0 & \multirow{2}{*}{29.4} & \multirow{2}{*}{$0.001 * *$} \\
\hline Female & 9 & 15.0 & & \\
\hline Total & \multicolumn{2}{|r|}{100} & & \\
\hline $\begin{array}{l}(N . B) \quad N . S . P>0 . C \\
* * P<0.001 \text { moderc }\end{array}$ & $\begin{array}{ll}* P \\
* * *\end{array}$ & sign & & \\
\hline
\end{tabular}

Table (2): Percent Distribution of the study sample in relation to their medical data $(\mathrm{N}=60)$

\begin{tabular}{|c|c|c|c|c|}
\hline \multirow[t]{2}{*}{ Variables } & \multicolumn{2}{|c|}{$\begin{array}{c}\text { Medical data of Study } \\
\text { sample } N=60\end{array}$} & \multirow[t]{2}{*}{ Chi-Square } & \multirow[t]{2}{*}{ P. value } \\
\hline & No & $\%$ & & \\
\hline $\begin{array}{l}\text { 1. Causes of admission } \\
\text { Traffic accident } \\
\text { Fall from high } \\
\text { Post-operative } \\
\text { Others } \\
\end{array}$ & $\begin{array}{c}27 \\
13 \\
14 \\
6 \\
\end{array}$ & $\begin{array}{c}45 \\
21.67 \\
23.33 \\
10 \\
\end{array}$ & 15.33 & $0.002 * *$ \\
\hline $\begin{array}{l}\text { 2. Diagnosis } \\
\text { Multiple fraction } \\
\text { Diabetic ketoacidosis } \\
\text { Brain edema } \pm \text { Trauma } \\
\text { Multiple cerebral contusion }\end{array}$ & $\begin{array}{c}36 \\
2 \\
9 \\
13\end{array}$ & $\begin{array}{c}60 \\
3.33 \\
15 \\
21.67\end{array}$ & 43.33 & $0.001 * *$ \\
\hline \begin{tabular}{|l|} 
3. Past History \\
Hepatitis $C$ virus \\
Hypertension \\
Diabetic \\
Others \\
No history \\
\end{tabular} & $\begin{array}{c}2 \\
13 \\
32 \\
8 \\
25 \\
\end{array}$ & $\begin{array}{r}3.33 \\
21.67 \\
53.33 \\
13.33 \\
41.67 \\
\end{array}$ & 36.7 & $0.001 * *$ \\
\hline
\end{tabular}

(N.B) N S .P $>0.05$ non-significant, $* P<0.05$ significant, $* * P<0.001$ moderate significant, $* * * P<0.0001$ highly significant

(N.B) There was more than one diagnosis and past medical history for every patient 
Table (3): Frequency distribution of the study sample in relation to the risk factors of pressure ulcer (60)

\begin{tabular}{|l|c|c|c|c|}
\hline \multirow{2}{*}{ Risk Factors } & \multicolumn{2}{|c|}{ Study sample N=60 } & \multirow{2}{*}{ Chi-Square } & \multirow{2}{*}{ P. value } \\
\cline { 2 - 3 } & No & \% & & \\
\hline Immobility & 49 & 81.67 & & \\
Obesity & 10 & 16.67 & & \\
Hypo-albuminaemia & 20 & 33.33 & & \\
Stroke & 11 & 18.33 & \multirow{2}{*}{131.0} & $0.001 * *$ \\
Hypertension & 9 & 15 & & \\
Reduced level of consciousness & 8 & 13.33 & & \\
Fracture or major orthopedic & 32 & 53.33 & & \\
Decreased perfusion & 3 & 5 & & \\
\hline
\end{tabular}

(N.B) N.S.P $>0.05$ non-significant, $* P<0.05$ significant, $* * P<0.001$ moderate significant $* * * P<0.0001$ highly significant,

(N.B) There was more than one risk factor for every patient.

Table (4): The mean and stander deviation of the anthropometric measurements among the study sample.

\begin{tabular}{|l|c|}
\hline \multicolumn{1}{|c|}{ Anthropometric measurement } & Study sample N=60 \\
\hline 1- Patient weight "kg" & $68.08+5.95$ \\
2- Patient height "cm" & $166.35 \pm 4.94$ \\
3- BMI "kg/m" & $26.96 \pm 2.5$ \\
4- Mid arm circumference" cm" & $24.83 \pm 2.94$ \\
\hline
\end{tabular}

(N.B) N.S.P $>0.05$ non-significant $\quad * P<0.05$ significant $\quad * * P<0.001$ moderate significant $* * * P<0.0001$ highly significant

Table (5 A): The mean and stander deviation of the hemodynamic parameters among the study sample $(\mathrm{N}=60)$

\begin{tabular}{|c|c|c|c|}
\hline Variables & Temperature $(\mathbf{c})$ & Pulse (b/m) & Respiration (c/m) \\
\hline Days & Study sample N=60 & Study sample N=60 & Study sample N=60 \\
\hline $\mathbf{1}^{\text {st }}$ day & $38.14+0.53$ & $106.6 \pm 23.07$ & $29.51 \pm 7.06$ \\
\hline $\mathbf{4}^{\text {th }}$ day & $37.97 \pm 0.5$ & $109.79 \pm 10.62$ & $28.7 \pm 6.54$ \\
\hline $\mathbf{7}^{\text {th }}$ day & $37.71+0.31$ & $110.67 \pm 14.89$ & $29.35+6.3$ \\
\hline P. value & $0.001^{* * \#}$ & $0.253 \#$ & $0.896 \#$ \\
\hline
\end{tabular}

\# This for $p$ value for comparison between first day and $7^{\text {th }}$ day.

(N.B) N.S.P $>0.05$ non-significant, $\quad * P<0.05$ significant,

$* * P<0.001$ moderate significant, $\quad * * * P<0.0001$ highly significant

Table (5 B): The mean and stander deviation of the blood pressure and pulse oximetry values among the study sample $(\mathrm{N}=60)$

\begin{tabular}{|c|c|c|}
\hline Va Variables & Study sample $(\mathbf{N}=60)$ & P. value \\
\hline $\begin{array}{l}\text { Systolic blood pressure } \\
1^{\text {st }} . \text { day } \\
4^{\text {th }} . \text { day } \\
7^{\text {th }} . \text { day }\end{array}$ & $\begin{array}{c}127.5 \pm 15.42 \\
124.67 \pm 13.28 \\
119.5 \pm 14.89\end{array}$ & $0.004 * * \#$ \\
\hline $\begin{array}{c}\text { Diastolic blood pressure: } \\
1^{\text {st }} . \text { day } \\
4^{\text {th }} . \text { day } \\
7^{\text {th }} . \text { day } \\
\end{array}$ & $\begin{array}{c}75 \pm 13.1 \\
74.34 \pm 14.34 \\
72.68 \pm 12.97 \\
\end{array}$ & $0.331 \#$ \\
\hline $\begin{array}{c}\text { Pulse oximetry : } \\
1^{\text {st }} \cdot \text { day } \\
4^{\text {th }} \cdot \text { day } \\
7^{\text {th }} \cdot \text { day } \\
\end{array}$ & $\begin{array}{l}97.83 \pm 2.29 \\
98.62 \pm 1.31 \\
99.15 \pm 0.83\end{array}$ & $0.001 * * \#$ \\
\hline
\end{tabular}

\# this for $p$ value for comparison between first day and $7^{\text {th }}$ day. (N.B) N.S.P $>0.05$ non-significant,

$* P<0.05$ significant, $* * P<0.001$ moderate significant $\quad * * * P<0.0001$ highly significant 
Table 6 (A): The mean and stander deviation of the arterial blood gases values (ABG) among the study sample (n=60).

\begin{tabular}{|c|c|c|c|}
\hline $\mathbf{V}$ Variables & PH & Pa & O2 \\
\hline Days & Study sample $(\mathbf{N = 6 0})$ & Study sample $(\mathbf{N = 6 0})$ & Study sample( $\mathbf{N = 6 0})$ \\
\hline $\mathbf{1}^{\text {st }}$ day & $7.42 \pm 0.08$ & $145.15 \pm 56.67$ & $35.69 \pm 5.83$ \\
\hline $\mathbf{4}^{\text {th }}$ day & $7.44 \pm 0.1$ & $139.21 \pm 31.44$ & $36.48 \pm 4.19$ \\
\hline $\mathbf{7}^{\text {th }}$ day & $7.48 \pm 0.06$ & $128.82 \pm 41.14$ & $35.29 \pm 3.84$ \\
\hline P. value & $0.001 * * \#$ & $0.073 \#$ & $0.658 \#$ \\
\hline
\end{tabular}

\# This for $p$ value for comparison between first day and $7^{\text {th }}$ day.

(N.B) NS.P>0.05 non-significant,

$* * P<0.001$ moderate significant,

$* P<0.05$ significant,

$* * * P<0.0001$ highly significant

Table 6 (B): The mean and stander deviation of the arterial blood gases (ABG) values among the study sample $(\mathbf{n}=60)$.

\begin{tabular}{|l|c|c|}
\hline & HCo3 & BE \\
\hline \hline It $\quad$ Items & Study sample $\mathbf{N = 6 0}$ & Study sample N=60 \\
\hline $\mathbf{1}^{\mathbf{s}} \quad{ }^{\mathbf{1} \mathbf{~ t}}$ day & $24.83 \pm 4.48$ & $5.27 \pm 4.64$ \\
\hline $\mathbf{4}^{\mathbf{t}} \quad{ }^{\text {th }}$ day & $26.29 \pm 3.51$ & $3.26 \pm 1.37$ \\
\hline $\mathbf{7}^{\mathbf{t}} \quad{ }^{\mathbf{7 t h}}$ day & $28.55 \pm 4.65$ & $4.74 \pm 3.97$ \\
\hline $\mathbf{P .} \quad$ P value & $0.001 * * \#$ & $0.503 \#$ \\
\hline
\end{tabular}

\# This for $p$ value for comparison between first day and $7^{\text {th }}$ day. (N.B) N.S.P $>0.05$ non-significant

$* P<0.05$ significant $\quad * * P<0.001$ moderate significant $\quad * * * P<0.0001$ highly significant

Table (7): The mean and stander deviation of the ventilator parameters values among the study sample $(\mathrm{n}=60)$.

\begin{tabular}{|c|c|c|}
\hline Variables & Study sample (N=60) & P. value \\
\hline $\begin{array}{l}\text { Respiratory rate: } \\
1^{\text {st }} . \text { day } \\
4^{\text {th }} . \text { day } \\
7^{\text {th }} . \text { day } \\
\end{array}$ & $\begin{array}{l}31.55 \pm 5.19 \\
33.22 \pm 8.57 \\
32.83 \pm 6.46\end{array}$ & $0.234 \#$ \\
\hline $\begin{array}{l}\text { Fio2: } \\
1^{\text {st }} \cdot \text { day } \\
4^{\text {th }} \cdot \text { day } \\
7^{\text {th }} \cdot \text { day } \\
\end{array}$ & $\begin{array}{c}47.12 \pm 5.4 \\
39.6 \pm 6.34 \\
43.75 \pm 2.71\end{array}$ & $0.001 * * \#$ \\
\hline $\begin{array}{l}\text { V.T: } \\
1^{\text {st }} \cdot \text { day } \\
4^{\text {th }} . \text { day } \\
7^{\text {th }} . \text { day }\end{array}$ & $\begin{array}{l}496.25 \pm 67.75 \\
513.85 \pm 54.99 \\
530.55 \pm 64.54\end{array}$ & $0.005 * * \#$ \\
\hline
\end{tabular}

\# this for $p$ value for comparison between first day and $7^{\text {th }}$ day.

(N.B) NS P >0.05 non-significant,

$* * P<0.001$ moderate significant,

\author{
$* P<0.05$ significant, \\ $* * * P<0.0001$ highly significant
}

Table (8): The mean and stander deviation of the Glasgow Coma Scale (GCS) values among the study sample $(n=60)$.

\begin{tabular}{|l|c|c|}
\hline \multicolumn{1}{|c|}{$\mathbf{D}$ days } & Study sample $(\mathbf{N}=\mathbf{6 0})$ & P. value \\
\hline $\mathbf{1}^{\text {st }}$ day & $4.75 \underline{ \pm 2.85}$ & \multirow{2}{*}{$0.001 * * \#$} \\
\hline $\mathbf{4}^{\text {th }}$ day & $7.55 \underline{ \pm 2.69}$ & \\
\hline $\mathbf{7}^{\text {th }}$ day & $7.54 \underline{ \pm 2.54}$ & \\
\hline
\end{tabular}

\# This for $p$ value for comparison between first day and $7^{\text {th }}$ day.

$\begin{array}{ll}(N . B) N . s . P>0.05 \text { non-significant } & * P<0.05 \text { significant } \\ * * P<0.001 \text { moderate significant } & * * * P<0.0001 \text { highly significant }\end{array}$ 
Table (9): The mean and stander deviation of the total fluid balance among the study sample $(n=60)$

\begin{tabular}{|c|c|c|}
\hline Days & Study sample (N=60) & P value \\
\hline $\mathbf{1}^{\text {st }}$.day & $1657.85 \pm 1095.24$ & \multirow{2}{*}{$0.350 \#$} \\
\hline $\mathbf{4}^{\text {th }} \cdot$ day & $1870.81 \pm 1375.73$ & \\
\hline $\mathbf{7}^{\text {h }} \cdot$ day & $2004.8 \pm 1424.42$ & \\
\hline
\end{tabular}

\# This for $p$ value for comparison between first day and $7^{\text {th }}$ day.

(N.B) NSP $>0.05$ non-significant, $* P<0.05$ significant, $* * P<0.001$ moderate significant

$* * * P<0.0001$ highly significant

Table (10): The mean and stander deviation of the Braden scale assessment values among the study sample $(n=60)$.

\begin{tabular}{|c|c|c|}
\hline Days/ Variables & Study sample $(\mathrm{N}=60)$ & $P$ value \\
\hline $1^{\text {st }}$. day $\backslash$ Mean \pm S.D & $11.47 \pm 1.5$ & \\
\hline $\begin{array}{l}\text { Severe risk"<9" } \\
\text { High risk "10-12" } \\
\text { Moderate risk "13-14" } \\
\text { Mild risk "15-18" }\end{array}$ & $\begin{array}{c}37(61.67 \%) \\
7(11.67 \%) \\
12(20.0 \%) \\
4(6.67 \%)\end{array}$ & $0.001 * *$ \#\# \\
\hline $4^{\text {th }}$. day $\backslash$ Mean \pm S.D & $12.98 \pm 1.94$ & \\
\hline $\begin{array}{l}\text { Severe risk"<9" } \\
\text { High risk "10-12" } \\
\text { Moderate risk "13-14" } \\
\text { Mild risk "15-18" }\end{array}$ & $\begin{array}{c}35(58.33 \%) \\
17(28.33 \%) \\
6 \quad(10.0 \%) \\
2(3.33 \%)\end{array}$ & $0.001 * * \# \#$ \\
\hline $7^{\text {th }}$. day $\backslash$ Mean \pm S.D & $14.07 \pm 2.61$ & \\
\hline $\begin{array}{l}\text { Severe risk"<9" } \\
\text { High risk "10-12" } \\
\text { Moderate risk " } 13-14 " \\
\text { Mild risk "15-18" }\end{array}$ & $\begin{array}{c}26(43.33) \\
6(10.0 \%) \\
10(16.67 \%) \\
18(30.0 \%)\end{array}$ & $0.001 * *$ \#\# \\
\hline P. value & $0.001 * * \#$ & \\
\hline
\end{tabular}

\#\# This for $p$ value for comparison between sub items of the Braden scale.

\# This for $p$ value for comparison between first day and $7^{\text {th }}$ day.

(N.B) NS.P $>0.05$ non-significant, $\quad * P<0.05$ significant.

$* * P<0.001$ moderate significant $\quad * * * P<0.0001$ highly significant

Figure (1): Age distribution for the studied sample.

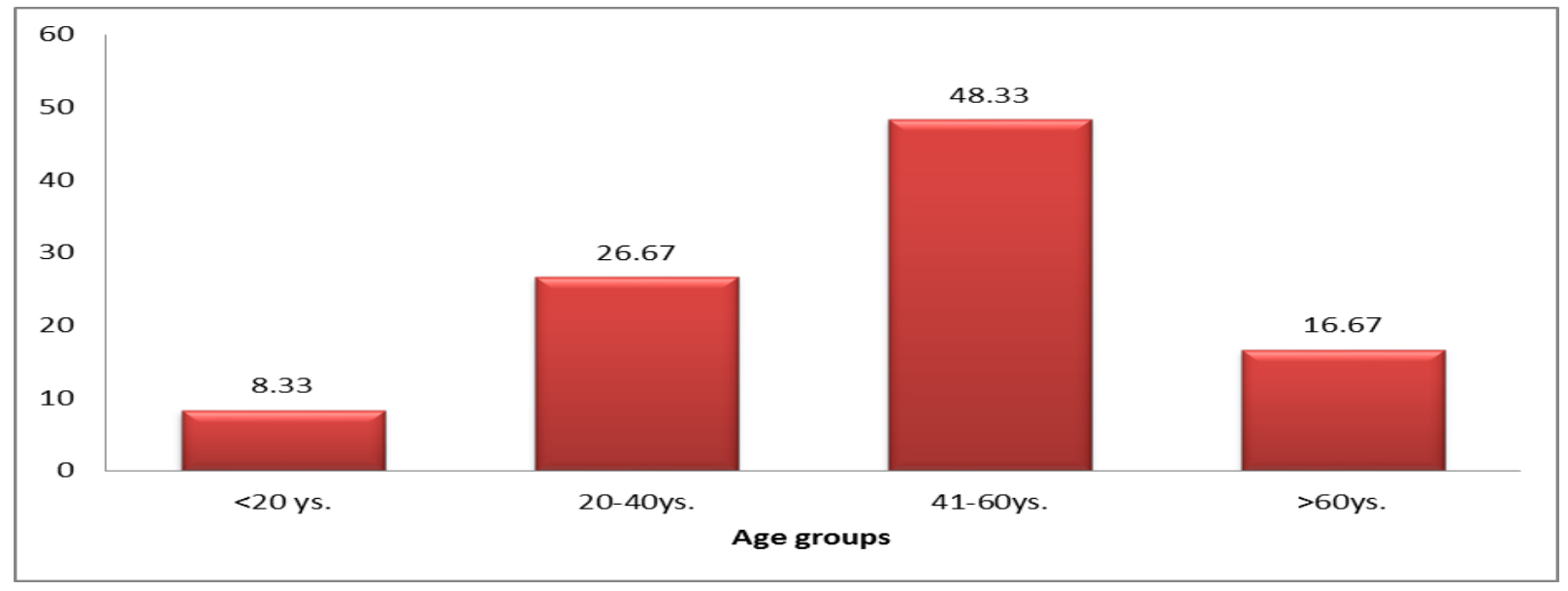


Figure (2): Sex distribution for the studied sample.

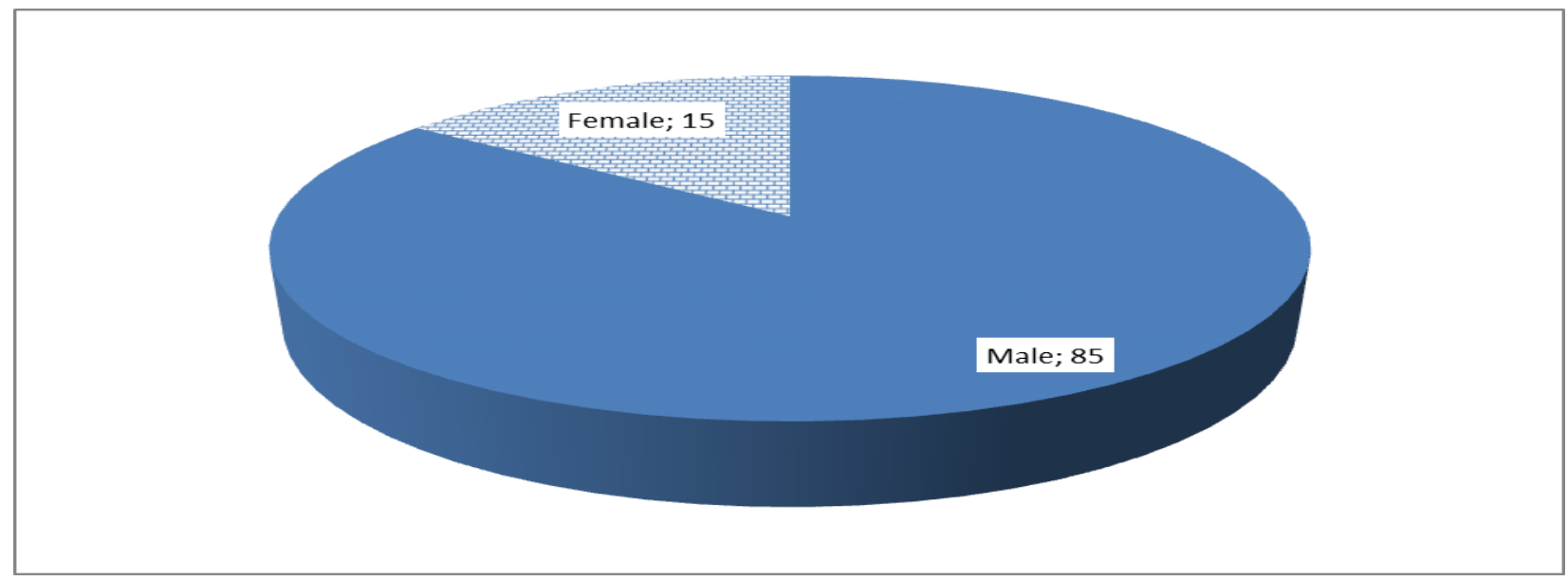

Figure (3): Distribution of the studied sample in relation to Risk factors.

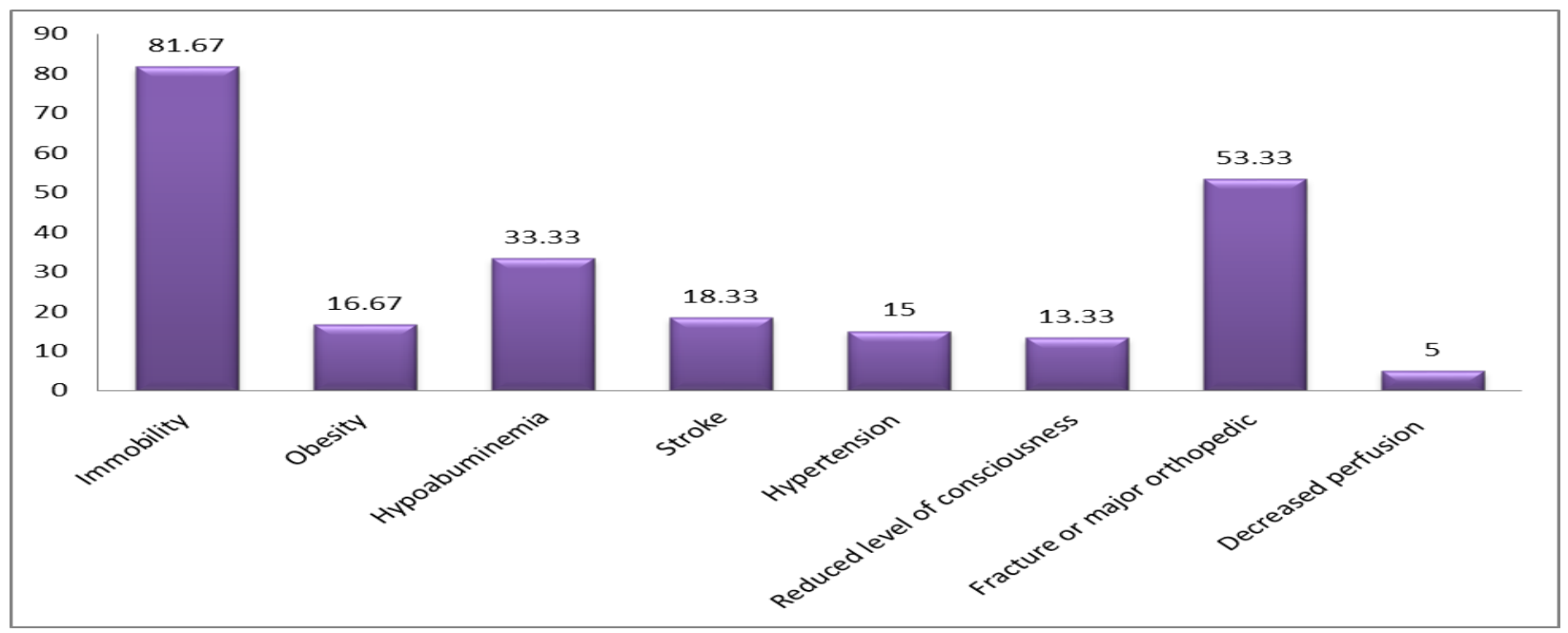

Figure (4): Assessment of skin using Braden scal

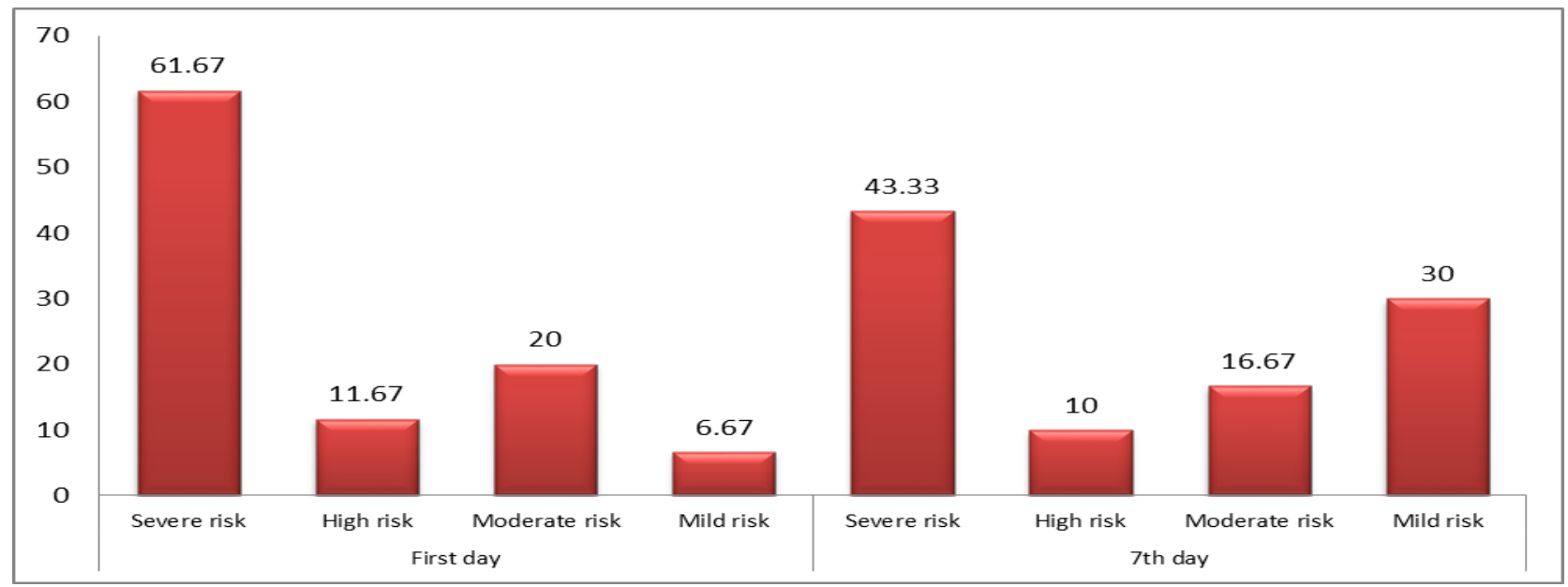


Table (1) : Represents frequency distribution of the study sample in relation to the sociodemographic characteristics that revealed most of the study sample aged 40-60 years old that represent $48.33 \%$ of the total sample, and there was a significance difference between the age groups with $\mathrm{P}$ value $=0.001$. Moreover, the majority of the sample was found to be males $(85.0 \%)$ and there was a significance difference between males and females with $\mathrm{P}$ value $=0.001$.

Table (2) : Shows the frequency distribution of study sample in relation to their medical data that reveled about $23.33 \%$ of the total sample was diagnosed as post-operative and $21.67 \%$ was diagnosed multiple cerebral contusion.

Table (3) : Indicates Frequency distribution of the study sample in relation to risk factors of pressure ulcer. results revealed that the majority of the studied patients were immobile $(81.67 \%)$, and it is the most important risk factor of pressure ulcer, then fracture or major orthopedic condition is the second risk factor of pressure ulcer with $53.33 \%$ of the study sample, and the last risk factors was hypoalbuminemia (16.67\%). There was a statistical significant difference between the study samples in relation to the risk factors.

Table (4) : Presents the mean and standard deviation of the anthropometric measurements values among the study sample that reveled mean of the studied patients' weight as $68.08 \pm 5.95$ and the mean of body mass index was found to be $(26.96+2.5)$.

Table (5 A) : Shows The mean and stander deviation of the vital signs and the hemodynamic parameters values of the study sample, there was a statistical significance difference with $\mathrm{p}$ value $=$ 0.001 among the studied patients between the first day and $7^{\text {th }}$ day in relation to the temperature values, but there was no statistical significance difference related to the pulse and respiration.

Table (5 B) : Reveals the mean and stander deviation of the blood pressure and pulse oximetry measurements values among the study sample, there was a statistical significance difference related to the systolic blood pressure and pulse oximetry measurements, but there was no statistical significance difference in relation to the diastolic blood pressure value.

Table (6) : (A \& B) shows the mean and stander deviation of the study arterial blood gases (ABG) values among the study sample, there was a significance difference between the first day and $7^{\text {th }}$ day as regard to $(\mathrm{PH} \& \mathrm{HCO} 3$ with $\mathrm{p}$ value $=0.001$, and there was no significance difference related to the $(\mathrm{PO} 2, \mathrm{PCO} 2 \& \mathrm{BE})$.
Table (7) : Indicates the mean and stander deviation of the ventilator parameters among the study sample, there was a significance difference between the first day and $7^{\text {th }}$ day related to (Fio2 \& V.T) with $\mathrm{p}$ value $=0.001,0.005$ respectively, and no significance difference related to respiratory rate.

Table (8) : Presents the mean and stander deviation of the Glasgow Coma Scale (GCS) value among the study sample, there was a significance difference between the first day and $7^{\text {th }}$ day with $p$ value $=0.001$

Table (9) : Demonstrates the mean and stander deviation of the total fluid balance among study sample; it was $1657.85 \pm 1095.24$ in the first day, and no significance difference between the first day and the $7^{\text {th }}$ day.

Table (10): Illustrates the mean and stander deviation of the Braden scale assessment value among the study sample, there was a significance difference between sub items of Braden scale $\mathrm{P}$ value $=0.001$.

\section{Discussion}

Pressure is a crucial factor in bed ulcer development, pressure of $70 \mathrm{~mm} \mathrm{Hg}$. over bony prominences for 2 hours or more is enough to cause an ischemic wound (Ferrcira, 2001). Individual who cannot independently reposition tend to be at the greatest risk for ulcer development Al-Shadedi, 2012. Pressure ulcer (PU) prevention is at the top of the list of hospital-acquired conditions that is almost exclusively within the realm of nursing practice. Indeed, PU prevention is listed as a "never event" by the Centers for Medicare \& Medicaid Service CMMS, 2008.

Present study revealed that most of the studied patients aged 41-60 years, they represented $48.33 \%$ of the studied sample, and there was a significance difference between the age groups. This finding was supported by a study done by Lauren, et al., 2005 with sample $(n=40)$ primarily consisted of Caucasian $(77.5 \%)$ individuals, the mean age of the sample was $56.37 \pm 14.6$ years, in contrast a study done by Manzano, et al., 2010 mentioned that the mean age was higher $(59 \pm 17 v s .67 \pm 14)$ in intervention and control group respectively. Advanced age is a risk factor for pressure ulcer development with several studies identifying that persons over age 70 are more susceptible to pressure ulcers result in the skin and support structures undergo changes in the aging process. There is a loss of muscle, a decrease in serum albumin levels, diminished inflammatory response, decreased elasticity, and reduced cohesion between the dermis 
and epidermis. These changes combine with other changes related to aging to make the skin less tolerant of pressure forces, shear, and friction

As regard the gender, the present study revealed that the majority of the studied patients were males, percentage of the male was $85.0 \%$ and there was significance difference between males and females with $p$ value $=0.001$. These finding was in line with study done by Eman, et al., 2009 who mentioned that the and $(43.8 \%)$ were females. Tschannen, et al., 2012 found that the majority of the patients were males. In the present study the majority of sample were males because all patient in trauma intensive unit during admission in this time was males and a lot of them were very thin and with major fracture. This came in contrast with the study done by Tsai, et al., 2012 that mentioned that majority of samples were females $(83.67 \%)$.

History of the studied patients' revealed previous disease of $\mathrm{HCV}$, diabetes mellitus and hypertension, there was significant difference among the study sample. A study done by Shahin, 2008 mentioned that comorbid conditions, including diabetes mellitus, sepsis, and vascular disease were significant factors for development of pressure ulcers in ICU patients.

As regard the body mass index the current study showed that the mean value was $(26.96 \pm 2.5)$ in the study sample. A study done by Van Gilder, et al., 2009 came in contrast with the current study, it was reported that pressure ulcers were more prevalent among patients with a lower BMI $(\mathrm{P}<.001)$, the mean BMI of patients in this study was 29.0 slightly higher than the mean BMI in the present study.

Regarding the risk factors of the pressure ulcer among the studied patients who admitted to the trauma Intensive Care at Assiut University Hospital whom they were at high risk for pressure ulcer, the risk factors were immobility, hypoalbuminemia, stroke, hypertension, reduced level of consciousness, fracture or major orthopedic, and decreased perfusion, they were the most common with a statistical significant difference. In the current study immobility seems to be the more common associated risk factor in development of pressure ulcer with a percentage of $81.67 \%$ of the total sample. After that came the fracture or major orthopedic, it was the second risk factor of pressure ulcer with $53.33 \%$ of the total sample, and then the hypoalbuminemia with $16.67 \%$, and there was a significant difference between all risk factors. This finding is in line with the study done by Anthony, et al., 2011 who documented that some patients who were hypoalbuminemia developed pressure ulcers. While in the study done by Marie. et al., 2012 mentioned that The most common risk factors in the studied group were hypertension, obesity, elevated cholesterol, and diabetes.

Results of the current study revealed that most of the studied patients experienced high mean body temperature value on admission with mean value greater than $38{ }^{\circ} \mathrm{c}$, there was a significance difference $(0.001)$ between the first day and $7^{\text {th }}$ day. But no significance difference related to the pulse and respiration. Lauren, et al., 2005 revealed that the mean HR for studied patients who developed pressure ulcer was $128.1 \pm 17.3 \mathrm{~b} / \mathrm{m}$. A statistically significant relationship was identified between heart rate and the lowest Braden Score $(\mathrm{r}=-0.254, \mathrm{p}=$ 0.057).

As regard monitoring of the blood pressure of the study sample on admission, the current study revealed that the mean score and SD of Systolic blood pressure was found to be $127.5 \pm 15.42$. There was a significance difference related to systolic blood pressure and pulse oximetry. As regard diastolic blood pressure in the present study showed no significant difference on admission with mean value of 75+13.1. In contrast, a study done by Cox, 2011 who found that patients in whom a pressure ulcer developed had significantly lower mean diastolic blood pressures, lower mean arterial pressure, and lower mean systolic blood pressures than did patients who remained free of pressure ulcers. However, none of these variables was a significant predictor. The finding that none of the blood pressure variables was a predictor of pressure ulcers in this study may be due to the frequent monitoring of blood pressure in critically ill patients, resulting in quicker implementation of interventions to increased arterial pressure.

Two studies done by Pender, 2005 \& Compton, et al., 2008 on ICU patients, documented that no significant relationships were found between any measure of blood pressure and development of pressure ulcers. In another study done by Seturan, et al., 2009 mentioned that the diastolic blood pressure was lower in critical care patients in whom pressure ulcers developed; however, this relationship was not statistically significant.

Arterial blood gases (ABGs) in the he present study showed that there was significance difference between the first day and $7^{\text {th }}$ day as regard to $\mathrm{PH} \&$ $\mathrm{HCO} 3$, with no significance difference related to the PO2, PCO2, \& BE. A study done by Lauren, et al., 2005 did not find a relationship between $\mathrm{PaCO} 2$, $\mathrm{PaO} 2$, and $\mathrm{SaO} 2$ and $\mathrm{PU}$ development. Thus, blood gas analysis may not be a sensitive indication of tissue oxygenation.

As regard to ventilator parameters the current study found a significance difference between the first day and $7^{\text {th }}$ day related to Fio2 \& V.T and no 
significance difference related to respiratory rate. Other studies done by Theaker, 2000, Eachempati, 2001, Fife 2001 \& Frankel 2007 described time on mechanical ventilation as a risk factor for pressure ulcer. Also study done by Manzano, 2010, only time on MV remained as a significant independent risk factor and increasing the risk of PU by $4.2 \%$ for every day on MV. Moreover, a study done by Lauren, et al., 2005 who mentioned that, $20 \%$ of the subjects on mechanical ventilation in the medical intensive care unit developed dermal pressure ulcers. Also a study done by Fife, et al., 2001 found that a prevalence of $12.4 \%$ in their sample of 186 neurological intensive care patients had pressure ulcer.

As regard to use skin assessment scale value (Braden scale) in the present study showed that the mean score and SD was $11.47 \pm 1.5$ on the day of admission. With significant difference at first day between sub items of the scale, but at the $7^{\text {th }}$ day the mean score and SD was $(14.07 \pm 2.61)$, with significance between $1^{\text {st }}$ and $7^{\text {th }}$ day. This study supported by study done by Lauren, et al., 2005 who mentioned that the Braden Score was a poor discriminator when attempting to predict which subjects in this study were at greatest risk for skin breakdown. The mean Braden Score on the day of admission for all subjects was $12.4 \pm 1.8$ and the lowest mean Braden Score for all subjects was $9.8 \pm$ 1.7. All of the subjects were identified at risk by the Braden Scale with low Braden Score values ranging from 6 to 14. In the Fife, et al., 2001 study, Braden Scores ranged from 8 to 23 , indicating greater variability in score.

A study done by (Cox, 2011) mentioned that, mean Braden Scale scores were 14.28 (SD, 2.68; range 623 ) for the entire patient sample, and it was 12.73 $\mathrm{SD}, 2.65$ for patients in whom pressure ulcers developed, and 14.63 SD, 2.65 for patients who remained ulcer-free. Of the 65 patients in whom a pressure ulcer developed, 28\% $(\mathrm{n}=18)$ were classified as at risk, 28\% $(\mathrm{n}=18)$ as at moderate risk, $35 \%(\mathrm{n}=23)$ as at high risk, and $9 \%(\mathrm{n}=6)$ as at very high risk.

\section{Conclusions}

Prevention of pressure ulcer requires the collaboration of all the nursing and surgical staff from different specialty. Development of pressure ulcer is the cause behind delay of patient discharge after successful treatment. Expectation of the development of pressure ulcer is significantly high in traumatized patients, bed ridden or immobility patients and hemiplegic patients.

\section{References}

1. Al-Shadedi A., (2012). Prevalence of Pressure Ulcers in Orthopaedic Patients THE IRAQI POSTGRADUATE MEDICAL JOURNAL, VOL.11, NO.4, P 529-535.

2. Anthony D., Rafter L., Reynolds T\& Aljezawi M., (2011). An evaluation of serum albumin and the sub-scores of the Waterlow score in pressure ulcer risk assessment, Journal of Tissue Viability, M Published by Elsevier Ltd; 20, 8999. www.elsevier.com/locate/jtv.

3. Armstrong D\& Bortz P, (2001). An integrative review of pressure relief in surgical patients. AORN J. 73:645 648, 650-653, 656-passim.

4. Ayello E\& Braden B, (2002). How and why to do pressure ulcer risk assessment. Adv skin Wd care. 15(3):125-131.

5. Braden B, (2011). Protocols by level of risk. http://www.bradenscale

.com/images/protocols_by_level_of_risk.pdf. Published 2001. Accessed June 4, 2011.

6. Compton F., Hoffmann F\& Hortig T,(2008). Pressure ulcer predictors in ICU patients: nursing skin assessment versus objective parameters. J Wound Care.17 (10):417-420, 22- 24.

7. Cox J., (2011), Predictors of pressure ulcers in adult critical care patients, ajcc american journal of critical care, volume 20, no. 5,p 364-474.

8. Crane B., Goehring $M$ \& Kunsman M, (2014).EVIDENCE BASED SOLUTIONS FOR IDENTIFICATION AND PREVENTION, p118. http://www.npuap.org/resources/educationaland-clinicalresources/ npuap-pressure-ulcerstagescategories.

9. Cullum N, (2001). Pressure ulcer prevention and treatment: a synopsis of the current evidence from research. Crit Care Nurs Clin North Am. 2001; 13:547-554.

10. Dickinson S., Tschannen D, (2013). Can the Use of an Early Mobility Program Reduce the Incidence of Pressure Ulcers in a Surgical Critical Care Unit? ; BY Wolters Kluwer Health | Lippincott Williams \& Wilkins; Vol. 36, No. 1, pp. 127-140.

11. Eman S., \& Ruud J, (2009). Incidence, prevention and treatment of pressure ulcers in intensive care patients: A longitudinal study; Elsevier Ltd. Available online at www.sciencedirect.com; pp. 413-421.

12. Fact sheet. (CMMS) Serious Adverse Events Working Group http://www.qualityforum.org. Accessed March 19, (2008).

13. Ferrcira L \& Calil J, (2001). The pressure ulcer, etiology and treatment. J Diag Treat; 6:3640 . 
14. Fife C., Otto G \& Capsuto E, (2001). Incidence of pressure ulcers in a neurologic intensive care unit. Crit Care Med; 29: 283-290.

15. Frankel H., Sperry J\& Kaplan L, (2007). Risk factors for pressure ulcer development in a best practice surgical intensive care unit. Am Surg. 73:1215- 1217.

16. Green, S., Cheerio\& Laddie (2011) Bidding Farewell to the Glasgow Coma Scale. Annals of emergency medicine, Vol 58 no(5) pp: 427-430.

17. Karadag M\& Gumuskaya N, (2006). The incidence of pressure ulcers in surgical patients: a sample hospital in Turkey. J Clin Nurs.2006;15:413-421.

18. Lauren R., Pender, Susan K\& Frazier, (2005). The relationship between dermal pressure ulcers, oxygenation and perfusion in mechanically ventilated patients, Elsevier Ltd, Accepted 13 July 21, 29-38.

19. Lyder C \& Ayello E, (2008). Pressure ulcers: a patient safety issue. In: Hughes R, ed. Patient Safety and Quality: An Evidence- Based Handbook for Nurses. Rockville, MD: Agency for Healthcare Quality and Research; AHRQ publication 08-0043.

20. Manzano F., Navarro M., Roldán D., Moral M\& Leyva I, (2010). Pressure ulcer incidence and risk factors in ventilated intensive care patients, Elsevier Inc, Journal of Critical Care, 25, 469-476 P 69-75.

21. Marie E., Pokorny, Dixie Koldjeski \& Melvin Swanson, (2012). Skin Care Intervention for Patients Having Cardiac Surgery; by AACN; Volume 12, No. 6, 115-124, Published online http://www.ajcconline.org . National pressure ulcer Advisory panel and European pressure ulcer Advisory panel (2009). Prevention and treatment of pressure ulcers: Clinical practice guideline. Washington DC: national pressure ulcer advisory panel.

22. Pender L\& Frazier S, (2005). The relationship between dermal ulcers, oxygenation and perfusion in mechanically ventilated patients. Intensive Crit Care Nurs; 21:9-38.

23. Reilly E., Karakousis G \& Schrag S, Stawicki S, (2007). Pressure ulcers in the intensive care unit: The 'forgotten' enemy, OPUS 12 Scientist Vol. 1, No. 2, 17-9.

24. Seturan L., Karabacak U\& Ozdilek S, (2009). The relationship among pressure ulcers, oxygenation, and perfusion in mechanically ventilated patients in an intensive care unit. $\mathbf{J}$ Wound Ostomy Continence Nurs. 36(5) pp: 503 508 .
25. Theaker C., Mannan M., Ives N \& Soni N, (2000). Risk factors for pressure sores in the critically ill. Anaesthesia.;55:221-4.

26. Thompson D, (2005). A., critical review of the literature on pressure ulcer etiology. J Wound Care. 2005; 14:87-90.

27. Tsai Y., Lin S., Liu Y\& and Wangb R, (2012). Factors related to the development of pressure ulcers among new recipients of home care services in Taiwan: A questionnaire study; Elsevier Ltd. NS-2043; No. of Pages1- 8 journal homepage: www.elsevier.com/ijns.

28. Tschannen D., Bates O., Talsma A \& Guo Y., (2012). Patient-specific and Surgical Characteristics in the Development of Pressure Ulcers, by AACN, Volume 21, No. 2,116-124.

29. Thomas D., (2001). Improving the outcome of pressure ulcers with nutritional interventions: a review of the evidence. Nutrition. b;17(2):121125.

30. Van Gilder C., MacFarlane G., Meyer S\& Lachenbruch C, (2009). Body mass index, weight, and pressure ulcer prevalence: an analysis of the 2006-2007 international pressure ulcer prevalence surveys. J Nurs Care Qual. 2009; 24(2):127-135.

31. Williams T., Leslie G., Bingham R\& Brearley L, (2012). Optimizing Seating in the Intensive Care Unit for Patients with Impaired Mobility, by AACN, AMERICAN JOURNAL OF CRITICAL CARE, January 2011, Volume 20, No. 1 P $18-2$ 